\title{
What Kind of Feedback is Perceived as Encouraging by Finnish General Upper Secondary School Students?
}

\author{
Toni Mäkipää * (D) and Raili Hildén \\ Faculty of Educational Sciences, University of Helsinki, 00014 Helsinki, Finland; raili.hilden@helsinki.fi \\ * Correspondence: toni.makipaa@helsinki.fi
}

\begin{abstract}
Our main aim in this study was to compare encouraging feedback practices in Finnish general upper secondary foreign language classes and examine how students perceive language teachers' assessment practices. The participants were 160 students of English, 95 students of Swedish, and 27 students of French from six general upper secondary schools. The data comprised one open-ended question and one Likert scale question with nine items. Both qualitative and quantitate methods were used to analyze the data. The results showed that content was the most important feature in feedback that was perceived as encouraging by students. The results further indicated that students considered teacher assessment practices to be primarily summative, but differences were also found between schools. The evidence from this study suggests that students appreciate teacher feedback, but do not perceive it to be an intrinsic part of teacher assessment practices. The importance of formative assessment and feedback should be more heavily emphasized in foreign language teacher education.
\end{abstract}

Keywords: feedback; formative assessment; general upper secondary education; Finland

check for updates

Citation: Mäkipää, T.; Hildén, R. What Kind of Feedback is Perceived as Encouraging by Finnish General Upper Secondary School Students? Educ. Sci. 2021, 11, 12. https:// doi.org/10.3390/educsci11010012

Received: 2 December 2020 Accepted: 28 December 2020 Published: 1 January 2021

Publisher's Note: MDPI stays neutral with regard to jurisdictional clai$\mathrm{ms}$ in published maps and institutional affiliations.

Copyright: (C) 2021 by the authors. Licensee MDPI, Basel, Switzerland. This article is an open access article distributed under the terms and conditions of the Creative Commons Attribution (CC BY) license (https:// creativecommons.org/licenses/by/ $4.0 /)$.

\section{Introduction}

The major objective in this study was to discern what kind of feedback encourages Finnish general upper secondary school students in foreign language classes. More specifically, we compared students' perceptions of feedback in Swedish, English, and French languages classes. Moreover, we examined what language teachers' assessment practices encompass, according to students. The data comprised one open-ended question on examples of encouraging feedback practices and one Likert scale question with nine items in which the participants indicated what is included in teacher assessment practices in language classes.

The core curriculum for general upper secondary education [1] advocates the notion of student-centered learning: students are active in their learning process, and learning is considered to be a consequence of goal-oriented and self-directed actions. By giving constructive feedback, teachers enhance students' confidence and thinking. Moreover, all the teachers should provide their students with feedback during the learning process, and assessment and feedback constitute focal parts of teacher and student interactions. With regard to the general objectives of learning Swedish (as Finland's other national language) and foreign languages, students should develop their skills in using learning strategies, comprehend the meaning of multifaceted language proficiency, work actively to become goal-oriented language learners, and develop language awareness.

Swedish, English, and French are "different" subjects in Finnish schools. Swedish and English are mandatory subjects, and pupils usually start to study English before Swedish. More than 90 percent of Finnish-speaking students study the "A" syllabus in English, whereas most students study the "B" syllabus in Swedish and French. The number of students who participate in the English test in the matriculation examination is much higher than in the Swedish or French test [2]. Moreover, students' attitudes to English are more positive than to Swedish (see [3]). 
Regarding assessment in general upper secondary education, it should be diverse and based on several issues. Teachers should use several assessment practices in their courses and one of the functions of assessment is to guide students in their learning process. In other words, assessment is not only about exams, essays, or other types of written work. Teachers should also take the formative aspect of assessment into account; namely, providing students with feedback and helping them discover their strengths and weaknesses. As a result, students learn more about themselves as learners [1]. Put differently, assessment should also guide students, not just grade them.

Feedback is a pivotal component of formative assessment, which is also referred to as assessment for learning. Giving feedback is an essential skill for teachers to have [4], and both the core curriculum for general upper secondary education [1] and the General Upper Secondary Schools Act [5] highlight the importance of feedback: teachers should give their students feedback in a range of ways. Moreover, feedback is a powerful tool for learning [6] as it also affects motivation and self-efficacy beliefs [7], and in this sense we all foster students' self-regulated learning [8]. All in all, feedback has a focal role in the learning process $[9,10]$. However, the quality of the feedback has a major effect on students in terms of whether the feedback encourages or discourages them [11]. Also, "many students are disengaged from the feedback process" [9] (p. 879), and students seem to receive less feedback on homework in higher grade levels (grades 5-12) [12]. Research on technology-enhanced feedback has stressed the importance of encouraging feedback as "pupils receiving mainly encouraging feedback reported the highest values indicating feedback as being beneficial for them" [13] (p. 10). Therefore, it is important to examine the perceptions of students about encouraging feedback in order to enhance assessment practices in education. Thus, our aim in this study was to investigate how the concept of teacher assessment practices differs between students and schools and the kinds of feedback Finnish general upper secondary school students find encouraging.

\subsection{Assessment Is about Decisions}

The traditional division between assessment types or strands tends to draw a somewhat simplistic border between summative and formative assessments, the first adhering to grading and selection and the latter to an ongoing process of promoting learning. Somewhere in between we find diagnostic assessment, a summary of previous learning outcomes and a starting point for a new track (e.g., [14,15]). However, the essence of assessment is neither its form nor its timing, but its consequences and impact that are mediated by the decisions based on assessment statements or test scores assigned to a particular performance [16]. While summative decisions of assessment may change the entire course of the life of a student or, in some highly test-driven contexts, even the fate of a teacher or a school, formative decisions are regarded as being less serious and more open-ended. Formative decisions pave the way for improved learning and often take the shape of advice, guidance, or recommendation instead of implementing a final conclusion that is difficult or impossible to change. Communicating formative assessment does not automatically exclude any reporting mode. The results of an instant small-scale classroom test can be reported in grades or scores, or in written or oral statements. All of these can be considered to be feedback to the student. Evaluative feedback can address a range of perspectives, such as effort and commitment to the task, strategies to carry out the task, the pace of completion, and the quality of the outcome in relation to resources. Corrective feedback can be either implicit or explicit, direct or indirect. In language teaching, implicit feedback encompasses conversational recasts, repetition, and clarification requests. Explicit correction can be given with or without metalinguistic explanation, didactic recast, elicitation, or various paralinguistic cues [17]. Feedback is a crucial tool in formative assessment [18,19] to guide and improve learning and it can take several forms and serve multiple functions.

In principle, feedback can be delivered by a teacher, peers, or the student him/herself, and at times, also by out-of-school collaborators or by automatic learning analytic devices. The nature of feedback can be conceptualized as input or as a dialogical process [20], 
with the current mainstream trend focusing on the latter dimension. The evidence base of feedback ranges from work samples in oral, written, or multimedia forms to informal observations of the process of work individually or in groups [20,21]. Ultimately, the aim of feedback is to increase students' self-efficacy, self-regulation, and motivation for life-long learning $[18,22]$.

\subsection{Students' Perceptions of Feedback and Assessment}

Many published studies have focused on students' perceptions of feedback and assessment. Prior research has substantiated the belief that students appreciate and value teacher feedback [23-25] and shown that students do not accept teachers not giving feedback at all [24]. Students find teacher feedback useful if they are aware of the learning goals and they exhibit high self-efficacy [26]. However, students do not seem to regard feedback as being as useful as their teachers do [27]. Moreover, students prefer comprehensive error treatment [24,28], as they do not find clues helpful [29]. Students want to get feedback on improvement [30] and teacher feedback should be tangible, honest, and critical [31]. Overall, students seem to be pleased with the quality of the feedback [27], although it has been reported in some studies that students find teacher feedback to be unclear (e.g., [10]). Additionally, students appreciate detailed and direct feedback [32]. However, overly detailed feedback can discourage students [33]. Students also want feedback during the learning process [34]. Regarding oral tasks, Martin and Alvarez Valdivia [25] found corrective feedback to be useful for learning but that students did not want to receive it too often. However, they found that more anxious students rated recast and metalinguistic feedback better.

Even though the number of studies focusing on students' perceptions about feedback has increased [35], far too little attention has been paid to the perceptions of general upper secondary school students of feedback or assessment in general in foreign languages in Finland. However, some studies have been conducted in recent years with students in basic or in general upper secondary education; Ilola [36] interviewed nine 9th grade English as a foreign language (EFL) students about their perceptions of the assessment of oral tasks. Based on the interviews, they pointed out that assessment and feedback enhance motivation and help students understand what needs to be improved. Nevertheless, students would like to have supportive feedback that states the strengths and weaknesses of the student instead of grades. Moreover, Pollari [37] studied the perceptions of 146 general upper secondary school EFL students with regard to how they had experienced assessment. The results indicated that most of the students were pleased with the assessment methods and felt that they took into account the knowledge and the skills of the students. However, it seems that teachers were more inclined to use summative methods, as one-third of the participants were not able to comment on the usefulness of formative assessment methods. The author concluded that the formative aspect of assessment should be emphasized more and assessment should be more diverse. Regarding empowerment, Pollari [38] studied what empowers and disempowers general upper secondary school EFL students. Based on survey answers from 146 students, assessment caused anxiety and stress for disempowered students who felt that they could not show what they were able to do in English with the assessment methods that teachers use. Instead, they would opt for more formative assessment. Regarding feedback, these students mentioned that they had not received enough feedback or that it had not helped them. In contrast, assessment was of more benefit to the nondisempowered students, who were more content with the assessment practices. However, the generalizability of these studies is problematic due to their sample sizes. Regarding the assessment practices in basic and general upper secondary education in Finland, Atjonen et al. [39] discovered that most of the assessment practices used by teachers are summative and noted that more attention should be paid to the enhancement of formative as well as interactive assessment practices. They also underscored that assessment should be used to guide students more. Similarly, Mäkipää and Ouakrim-Soivio [40] found that general upper secondary school teachers are prone to 
using summative assessment methods and that students often report a lack of feedback during courses.

\subsection{Language Learning, Motivation and Feedback}

While a variety of definitions of the term motivation have been suggested, a precise definition has proved elusive. Although differences of opinion exist, there seems to be some agreement that motivation primarily concerns choice, persistence, and effort. Put differently, motivation explains why people do something, how long they do it, and how hard they pursue the goal [41] (p. 4). In a school context, feedback given by teachers enhances motivation [41,42], and particularly intrinsic motivation [42], which refers to actions executed due to genuine interest in something. By contrast, extrinsic motivation refers to actions executed to obtain something useful [43]. In their classic study, Gardner and Lambert [44] demonstrated that motivation has a substantial effect on second language learning. If students lack motivation, even excellent teaching does not accelerate learning [45].

Many published studies have described the relationship between teachers' feedback and students' motivation. Regarding writing, students perceive both positive and negative comments as being useful for learning and both types of comments also constitute a source of motivation [28]. Cauley and McMillan [46] underscored the notion of formative assessment and using informative comments. Feedback can encourage self-assessment or "influence how students attribute their successes" (p. 4). In contrast, normative feedback, which refers to comparing students, only increases motivation for extrinsic reasons. This view is supported by Dörnyei [47], who pointed out that teachers should regularly give feedback to their students on their progress, and by Murtagh [48], who underlined the importance of descriptive feedback instead of phatic and evaluative feedback. Regarding intrinsic motivation, "assessment practices that build on monitoring and scaffolding increase the motivation of students" [49] (p. 453). Moreover, the teacher's proximity helps when giving students feedback on their learning [49]. Similarly, Weurlander et al. [50] found that formative assessment can enhance intrinsic motivation in students, namely in students who have an interest in the subject at hand. However, they also found evidence for the effects of formative assessment on external motivation, namely in the pressure to study. Moreover, feedback and assessment can enhance students' motivation if they "are used for their intended purposes" [31] (p. 248).

\subsection{Research Questions}

As feedback constitutes an integral part of assessment and teaching, our aim in this paper is to compare encouraging feedback practices in Finnish general upper secondary foreign language classes and to examine how students perceive the concept of teachers' assessment practices. This paper is structured around three research questions:

1. How does the concept of teacher assessment practices differ between students studying English, Swedish, and French?

2. How does the concept of teacher assessment practices differ between students at average schools and reputable schools?

3. What kind of feedback do Finnish general upper secondary school students find encouraging?

"Feedback" here refers to teacher feedback to students, and "encouraging feedback" refers to feedback that students find inspiring and helpful. With regard to schools, "average schools" refers to schools with average-achieving students, whereas "reputable schools" refers to schools with high-achieving students.

\section{Methodology}

The data for this study were collected from 282 general upper secondary school students from six schools in several Finnish regions. Among the students, 95 were boys and 185 were girls. Two students did not indicate their gender. With regard to languages, 
there were 160 students of English, 95 students of Swedish, and 27 students of French. The participants were aged 17 to 19 years and the necessary research permission for conducting research in schools was obtained. With regard to language choices, Finland is a bilingual country with two official languages: Finnish and Swedish. Students whose mother tongue is Finnish must study Swedish as a second national language and vice versa. Every student in the Finnish school system must study one compulsory syllabus in the second national language, Finnish or Swedish depending on one's mother tongue, and one advanced syllabus in a foreign language, which is customarily English. Students can also study optional languages, such as French, but it is not compulsory to choose a third language.

The students came from two types of school: average $(n=169)$ and reputable $(n=111)$. Two students did not indicate their school. The division was based on the grade point average (GPA) needed to enter the school. In reputable schools, the grade point averages were above nine (on a scale from four to ten), and in average schools they were between 7.3 and 7.5. The reputable schools in this study could even be called schools for the gifted: even though Finnish legislation does not recognize "gifted" education, it its extremely difficult to be accepted into these schools due to the high grade point average required. Moreover, one of these schools emphasizes foreign languages and could therefore be labeled as a special school, and it is also difficult to be accepted into these types of schools [51]. Moreover, it can be argued that differences in students' backgrounds can also be detected: students at reputable schools are more likely to come from wealthier families and districts. Swedish students came from three reputable and one average school, whereas English students came from two reputable and two average schools. French students came from one reputable and one average school.

Table 1 displays the previous course grades of the students in each language and by school. Eight students did not remember their previous grade.

Table 1. Means of the previous course grades by language and by school.

\begin{tabular}{cccccccc}
\hline Language & Average Schools & \multicolumn{3}{c}{ Reputable Schools } & \multicolumn{3}{c}{ All } \\
\hline & $\mathrm{M}$ & S.D. & $\mathrm{M}$ & S.D. & $p$ & $\mathrm{M}$ & S.D. \\
English & 7.83 & 1.28 & 8.60 & 0.74 & $0.000^{*}$ & 8.07 & 1.19 \\
Swedish & 7.70 & 1.54 & 8.26 & 1.16 & $0.047^{*}$ & 8.02 & 1.36 \\
French & 8.84 & 0.83 & 9.25 & 1.04 & 0.290 & 8.96 & 0.90 \\
All & 7.91 & 1.35 & 8.48 & 1.02 & $0.000^{*}$ & \\
\hline
\end{tabular}

Note : $\mathrm{M}=$ mean, S.D. $=$ standard deviation, ${ }^{*}=p<0.05$; Grades in Finnish schools range from four (failed) to ten (excellent).

As Table 1 shows, the means were always higher, for every comparison, in reputable schools, and statistically significant differences were present for English, Swedish, and between the schools. No difference was detected in French, probably due to the small sample size.

All the participants answered an online survey on feedback and assessment practices between November 2018 and September 2019. The survey was part of a wider study examining feedback practices in Finnish foreign language classes. The survey included closed-ended questions with a Likert scale $(1=$ strongly disagree, $5=$ strongly agree $)$ and one open-ended question. For this study, the answers to the open-ended question and one closed-ended question with nine items were analyzed. In the open-ended question, the students were asked to give examples of encouraging feedback practices. In the closedended question, there were nine assessment-related items, and the students rated whether these items were salient for teacher assessment practices. These items were based on the core curriculum and the different functions of assessment. 


\section{Data Analysis}

The open-ended answers were analyzed using qualitative content analysis with an inductive approach. As we did not have specific expectations about the students' answers or of the categories that would emerge from the data, an inductive approach was used [52].

When qualitative data are divided into codes, the first step for the researcher is to become familiar with the data. Consequently, the researcher starts to notice patterns and connections [53]. The first author read through the data three times prior to coding the data using Atlas.ti. Coding refers to "the process of examining data, identifying and noting aspects that relate to your research questions". If all the data are analyzed, coding is complete, whereas if only some of the data are analyzed, coding is selective [54] (p. 328). As all the data were analyzed in this study, the coding was complete. Based on this definition, the unit of analysis was a single word, a sentence, or a combination of sentences expressing only one thought. As a result, 880 units were coded, and five main categories emerged from the analysis: content, nature, mode, process, and other issues. Subcategories were subsequently created to elaborate on the main categories. The second author agreed with the first author on the categories, how they were formed, and how the subcategories were created, which increases the reliability of this study.

Regarding content, all the units focusing on the content of an assignment, presentation, or another type of work, such as mistakes or how to improve the work, were grouped under "content", whereas units that described feedback with adjectives, such as clear or positive, were grouped under "nature". "Mode" referred to the form of the feedback whereas units describing the learning process in any way were grouped under "process". "Other issues" referred to issues that did not adhere to any of these categories.

The quantitative data were analyzed in SPSS version 25. One-way MANOVA was used to investigate what language teachers' assessment practices encapsulate according to English, Swedish, and French students. In turn, one-way ANOVA was used to compare the perceptions of students of average and reputable schools. If statistically significant differences occurred, post-hoc (Tukey) tests were also used.

\section{Results}

First, the quantitative results with regard to teachers' assessment practices are presented and discussed. Then, the qualitative results with regard to encouraging feedback practices are presented and discussed.

\subsection{Teachers' Assessment Practices According to English, Swedish, and French Students}

For the first research question, a one-way MANOVA was conducted to compare the means of the responses of English, Swedish, and French students regarding teachers' assessment practices in foreign languages. The question included nine items and the students evaluated whether they were important in teachers' assessment practices. The multivariate result was significant for language, Wilks' $\Lambda=0.818, \mathrm{~F}=3.083, \mathrm{df}=2, p=0.000$, indicating a difference across languages. Table 2 presents the results of the analyses.

As shown in Table 2, Swedish students seemed to associate assessment primarily with grading exams (3.68) and giving course grades (3.60). Giving feedback (2.35) had the lowest mean. With regard to English students, they considered assessment to be primarily assessing essays (3.61) and other written tasks (3.61), as well as grading exams (3.52). Assessing oral skills had the lowest mean (2.48), and giving feedback had the second lowest mean (2.56). French students considered assessment primarily to be giving course grades (3.48), assessing essays (3.41), other written tasks (3.41), and exams (3.41), and enhancing learning (3.41). Assessing oral skills had the lowest mean (3.07), and giving feedback had the second lowest mean (3.15). 
Table 2. Means of the responses of English, Swedish, and French students regarding teachers' assessment practices.

\begin{tabular}{|c|c|c|c|c|c|c|c|}
\hline \multirow[b]{2}{*}{ Dependent Variable } & \multirow[b]{2}{*}{ df } & \multirow[b]{2}{*}{$\begin{array}{c}\text { df } \\
\text { Error }\end{array}$} & \multirow[b]{2}{*}{$\mathbf{F}$} & \multirow[b]{2}{*}{ La } & \multirow[b]{2}{*}{$\mathbf{M}$} & \multicolumn{2}{|c|}{$\begin{array}{l}99.9 \% \text { Confidence } \\
\text { Interval }\end{array}$} \\
\hline & & & & & & $\begin{array}{l}\text { Lower } \\
\text { Bound }\end{array}$ & $\begin{array}{l}\text { Upper } \\
\text { Bound }\end{array}$ \\
\hline \multirow{4}{*}{ Assessing essays } & \multirow{4}{*}{2} & \multirow{4}{*}{526} & \multirow{4}{*}{1.080 \# } & En & 3.61 & 3.39 & 3.84 \\
\hline & & & & Sw & 3.48 & 3.17 & 3.79 \\
\hline & & & & Fr & 3.41 & 2.69 & 4.13 \\
\hline & & & & En & 2.80 & 2.51 & 3.10 \\
\hline \multirow[t]{3}{*}{ Assessing word tests } & \multirow[t]{3}{*}{2} & \multirow[t]{3}{*}{526} & \multirow[t]{3}{*}{$7.602 *$} & Sw & 3.30 & 2.96 & 3.63 \\
\hline & & & & $\mathrm{Fr}$ & 3.30 & 2.59 & 4.00 \\
\hline & & & & En & 3.61 & 3.35 & 3.86 \\
\hline \multirow[t]{3}{*}{ Assessing written work } & \multirow[t]{3}{*}{2} & \multirow[t]{3}{*}{526} & \multirow[t]{3}{*}{$1.329 \#$} & Sw & 3.43 & 3.10 & 3.75 \\
\hline & & & & Fr & 3.41 & 2.74 & 4.07 \\
\hline & & & & En & 2.48 & 2.19 & 2.77 \\
\hline \multirow{3}{*}{ Assessing oral work } & \multirow[t]{3}{*}{2} & \multirow[t]{3}{*}{526} & \multirow[t]{3}{*}{$3.824 *$} & Sw & 2.50 & 2.16 & 2.84 \\
\hline & & & & $\mathrm{Fr}$ & 3.07 & 2.19 & 3.96 \\
\hline & & & & En & 3.49 & 3.23 & 3.75 \\
\hline \multirow[t]{3}{*}{ Giving course grades } & \multirow[t]{3}{*}{2} & \multirow[t]{3}{*}{526} & \multirow[t]{3}{*}{$0.387 \#$} & Sw & 3.60 & 3.27 & 3.93 \\
\hline & & & & $\mathrm{Fr}$ & 3.48 & 2.73 & 4.23 \\
\hline & & & & En & 3.52 & 3.24 & 3.79 \\
\hline \multirow[t]{3}{*}{ Assessing exams } & \multirow[t]{3}{*}{2} & \multirow[t]{3}{*}{526} & \multirow[t]{3}{*}{$1.189 \#$} & Sw & 3.68 & 3.35 & 4.01 \\
\hline & & & & Fr & 3.41 & 2.71 & 4.10 \\
\hline & & & & En & 2.97 & 2.69 & 3.26 \\
\hline Enhancing learning & 2 & 526 & $3.710 *$ & Sw & 2.78 & 2.41 & 3.15 \\
\hline & & & & Fr & 3.41 & 2.56 & 4.25 \\
\hline & & & & En & 2.75 & 2.44 & 3.05 \\
\hline Recognizing strengths & 2 & 526 & $7.978^{*}$ & Sw & 2.44 & 2.07 & 2.80 \\
\hline & & & & $\mathrm{Fr}$ & 3.37 & 2.55 & 4.19 \\
\hline & & & & En & 2.56 & 2.28 & 2.85 \\
\hline Giving feedback & 2 & 526 & $6.083 *$ & Sw & 2.35 & 2.01 & 2.69 \\
\hline & & & & $\mathrm{Fr}$ & 3.15 & 2.23 & 4.07 \\
\hline
\end{tabular}

Note 1: $\mathrm{La}=$ Language, En $=$ English, $\mathrm{Sw}=$ Swedish, $\mathrm{Fr}=$ French. Note $2:{ }^{*}=p<0.05, \#=$ not significant. $\mathrm{M}=$ mean.

Statistically significant differences were found for five items: assessing word tests $(p=0.001)$, assessing oral work $(p=0.023)$, enhancing learning $(p=0.026)$, recognizing strengths $(p=0.000)$, and giving feedback $(p=0.003)$. As the data were not evenly distributed, follow-up nonparametric Kruskal-Wallis tests were used to investigate the relationship between the perceptions of students and languages. The follow-up tests showed that there was no statistically significant difference in assessing oral work $(p=0.070)$. Consequently, this variable was excluded from the post hoc tests.

Post hoc comparisons using the Tukey test indicated that, with regard to word tests, differences were found between Swedish and English $(p=0.001)$. Regarding enhancing learning, differences were found between Swedish and French $(p=0.021)$. With regard to recognizing strengths, differences were found between Swedish and French $(p=0.0000)$ and between French and English $(p=0.0018)$. With regard to giving feedback, differences were found between Swedish and French $(p=0.002)$ and between French and English (p. $=0.022)$.

These results imply that students do not regard feedback to be an important part of teachers' assessment in foreign languages, as it had the lowest mean among Swedish students, and the second lowest among both English and French students. Assessing oral work, in turn, had the lowest mean among French and English students, and the third lowest among Swedish students. 


\subsection{The Concept of Teachers' Assessment Practices in Different Schools}

Regarding the second research question, a one-way ANOVA was conducted to compare the students' perceptions of teacher assessment practices in both types of school. The differences between the schools are highlighted in Table 3.

Table 3. Perceptions of teachers' assessment practices in general upper secondary schools.

\begin{tabular}{cccccccccc}
\hline Variables & \multicolumn{2}{c}{ Average Schools } & \multicolumn{2}{c}{ Reputable Schools } & & & \\
& M & S.D. & M & S.D. & df & MS & F & $p$ & $\boldsymbol{\eta}^{\mathbf{2}}$ \\
\hline Assessing essays & 3.55 & 0.89 & 3.54 & 0.87 & 1 & 0.012 & 0.016 & 0.901 & 0.00 \\
Assessing word tests & 3.00 & 1.12 & 3.06 & 0.99 & 1 & 0.198 & 0.174 & 0.677 & 0.00 \\
Assessing written work & 3.55 & 0.94 & 3.50 & 0.95 & 1 & 0.186 & 0.209 & 0.648 & 0.00 \\
Assessing oral work & 2.63 & 1.09 & 2.41 & 1.02 & 1 & 3.207 & 2.854 & 0.092 & 0.01 \\
Giving course grades & 3.59 & 0.92 & 3.43 & 1.00 & 1 & 1.556 & 1.711 & 0.192 & 0.01 \\
Assessing exams & 3.62 & 0.95 & 3.48 & 1.03 & 1 & 1.261 & 1.305 & 0.254 & 0.01 \\
Enhancing learning & 3.05 & 1.06 & 2.80 & 1.11 & 1 & 4.315 & 3.700 & 0.055 & 0.01 \\
Recognizing strengths & 2.83 & 1.10 & 2.52 & 1.12 & 1 & 6.145 & 5.009 & $0.026^{*}$ & 0.02 \\
Giving feedback & 2.70 & 1.04 & 2.34 & 1.07 & 1 & 8.283 & 7.453 & $0.007^{*}$ & 0.03 \\
\hline
\end{tabular}

Note 1: $\mathrm{M}=$ mean, S.D. = standard deviation, $\mathrm{MS}=$ mean squares, ${ }^{*}=p<0.05, \eta^{2}=$ partial eta squared. $\mathrm{F}=$ variation between sample means.

As we can see from Table 3, assessment was primarily perceived as assessing essays (3.62) and giving course grades (3.59), according to students from average schools. Giving feedback (2.70) had the lowest mean. In contrast, students from reputable schools associated assessment primarily with assessing essays (3.54) and assessing written work (3.50). Giving feedback (2.43) again had the lowest mean. The students from average schools had a higher mean in eight variables. The students at reputable schools had a higher mean only in assessing word tests.

A comparison of the two types of school reveals that assessing essays, written work, and exams, as well as giving course grades, were rated quite highly by students from both school types. In contrast, giving feedback, assessing oral work, and recognizing students' strengths were rated low. However, two statistically significant differences were found between the schools: students at average schools rated giving feedback $(p=0.007)$ and recognizing students' strengths $(p=0.026)$ higher than students at reputable schools. As the data were not evenly distributed, follow-up nonparametric Mann-Whitney $U$ tests were used to examine the relationship between the perceptions of students and schools. The test revealed the same two variables with statistically significant differences.

To sum up the results, the content of the feedback was the most important feature in encouraging feedback for each language. Regarding the concept of assessment, it was primarily perceived to be about grading exams and course grades; in other words, summative assessment. The notion of feedback had an extremely low mean among English and Swedish students, whereas French students regarded feedback to be a salient part of assessment. In addition, students at average and reputable schools associated teacher assessment practices with exams and course grades especially. However, students at average schools were also more inclined to associate feedback and the learning process with assessment.

\subsection{Encouraging Feedback Practices According to Students}

The aim of the third research question was to investigate encouraging feedback practices in language classes in general upper secondary schools. Among the answers, five issues were mentioned by only one student and these were excluded from the table. Table 4 presents the results obtained from the content analysis. 
Table 4. Encouraging feedback practices according to general upper secondary school students.

\begin{tabular}{|c|c|c|c|c|c|c|c|}
\hline & & English & & Swedish & & French & \\
\hline Categories & Subcategories & $\%$ & $\mathrm{~N}$ & $\%$ & $\mathrm{~N}$ & $\%$ & $\mathrm{~N}$ \\
\hline \multirow[t]{8}{*}{ Content } & & 51 & 209 & 47 & 131 & 55 & 51 \\
\hline & Mistakes & 15 & 60 & 17 & 47 & 10 & 9 \\
\hline & Cons & 5 & 21 & 4 & 11 & 4 & 4 \\
\hline & Pros & 15 & 62 & 11 & 31 & 18 & 17 \\
\hline & What to improve & 12 & 51 & 11 & 31 & 13 & 12 \\
\hline & Tangible tips & 3 & 12 & 3 & 9 & 8 & 7 \\
\hline & Where student has improved & 1 & 3 & 1 & 2 & - & - \\
\hline & Spelling & - & - & - & - & 2 & 2 \\
\hline \multirow[t]{5}{*}{ Nature } & & 33 & 138 & 32 & 89 & 29 & 27 \\
\hline & Differentiated & 1 & 3 & 3 & 8 & 1 & 1 \\
\hline & Critical & 13 & 55 & 9 & 25 & 11 & 10 \\
\hline & Positive & 13 & 54 & 14 & 39 & 11 & 10 \\
\hline & Clear and unambiguous & 6 & 26 & 6 & 17 & 7 & 6 \\
\hline \multirow[t]{5}{*}{ Mode } & & 9 & 39 & 12 & 34 & 7 & 6 \\
\hline & Written & 5 & 21 & 5 & 15 & 2 & 2 \\
\hline & Oral & 2 & 7 & 3 & 9 & 3 & 3 \\
\hline & Individual & 3 & 11 & 3 & 7 & 1 & 1 \\
\hline & In/after class & - & - & 1 & 3 & - & - \\
\hline \multirow[t]{6}{*}{ Process } & & 5 & 21 & 6 & 15 & 9 & 8 \\
\hline & How to change learning & 1 & 5 & 2 & 5 & 2 & 2 \\
\hline & How to enhance skills & 3 & 11 & 3 & 9 & 7 & 6 \\
\hline & Mid-term assessment & 0 & 1 & 0 & 1 & - & - \\
\hline & How to affect course grade & 1 & 2 & - & - & - & - \\
\hline & $\begin{array}{c}\text { Continuous feedback during } \\
\text { the course }\end{array}$ & 1 & 2 & - & - & - & - \\
\hline \multirow[t]{6}{*}{ Other Issues } & & 2 & 7 & 3 & 9 & $\mathbf{0}$ & $\mathbf{0}$ \\
\hline & $\begin{array}{l}\text { Dissatisfaction with current fb } \\
\text { practices }\end{array}$ & 1 & 2 & 1 & 2 & - & - \\
\hline & $\mathrm{Fb}$ does not motivate & 0 & 1 & 1 & 2 & - & - \\
\hline & I do not know & 0 & 1 & 1 & 2 & - & - \\
\hline & All fb helps & - & - & 1 & 2 & - & - \\
\hline & Scoring & 1 & 3 & 0 & 1 & - & - \\
\hline TOTAL & & 100 & 414 & 100 & 278 & 100 & 92 \\
\hline
\end{tabular}

Note: $\mathrm{N}$ = number of participants raising the issue, - = data not obtained, $\mathrm{Fb}$ = feedback; The numbers are rounded up; Issues mentioned by only one student were excluded from the table.

To illustrate the main categories, examples of students' answers for each category are provided.

1. Nature: "Feedback that has been clearly stated." (English)

2. Process: "(The teacher) explains... how I could improve my studying." (English)

3. Content: "(The teacher) corrects the grammar mistakes." (French)

4. Mode: "Oral... feedback after for instance a writing assignment." (Swedish)

5. Other issues: "Teachers do not give enough feedback if writing and speaking are fluent." (English)

As portrayed in Table 4, the content of the feedback was the category mentioned most often for English students, with 50\% of the answers focused on it. The second most mentioned category was the nature of the feedback (33\%), followed by the mode $(9 \%)$, the learning process $(5 \%)$, and other issues $(2 \%)$. Similarly, Swedish students referred to content most often $(47 \%)$, followed by the nature of feedback $(32 \%)$, the mode $(12 \%)$, the learning process $(5 \%)$, and other issues (3\%). In contrast, the answers of French students differed slightly. The content (55\%) was the most mentioned category, followed by the nature of feedback $(29 \%)$, the learning process $(9 \%)$, and the mode $(7 \%)$. 
A comparison of the languages reveals several noteworthy differences. First, the content of feedback was the most often mentioned category in encouraging feedback in each language, followed by the nature of feedback. Second, the third most often mentioned category was the mode for Swedish and English students, whereas for French students it was the process. Third, feedback on spelling was only mentioned by two French students. Fourth, both English and French students were unanimous about the importance of critical and positive feedback in the quality of feedback. In contrast, Swedish students heavily emphasized positive feedback over critical feedback. Fifth, feedback on the learning process was in turn mentioned more by the French students than by English or Swedish students. Sixth, only Swedish students addressed feedback both in lessons and after them and stated that all feedback motivated them. Moreover, only English students stated that they wanted feedback continuously in courses and that they wanted feedback on how to affect the course grade. Finally, French students did not mention mid-term assessment, which was mentioned by both English and Swedish students.

\section{Discussion}

The findings from this study reveal several salient aspects of feedback practices in language classes. With regard to previous research, the results are consistent with several studies: students want to receive feedback on how to improve their work [30], teacher feedback should be tangible and critical [31], and students want to receive feedback on their errors $[24,28]$. As students want to improve their work with teacher feedback, it can be concluded that they also appreciate teacher feedback [23-25]. In contrast to earlier findings, however, students in this study did not particularly want to receive feedback on the learning process [34]. Nevertheless, it is apparent that the French students found feedback on the learning process more encouraging than the Swedish or English students. Similarly, the quantitative results show that the French students perceived teachers' assessments to be more relevant to the learning process than their English and Swedish peers. A probable explanation is that the French students were a select group of students who were genuinely interested in learning languages and possessed the skills and strategies needed to successfully learn them, as French is an optional language at Finnish schools. Put differently, students who struggle with languages or have learning difficulties do not usually choose an optional language. Moreover, this result can be explained by the fact that teachers use different teaching methods in French lessons compared to Swedish or English lessons; for instance, French teachers encourage their students to use French in their spare time more than English or Swedish teachers [55].

Another notable observation from the data is that Swedish students, compared to English and French students, clearly preferred positive to critical feedback. One reason for this could be that students are generally weak in Swedish and have a negative attitude to it [56]. Thus, students might hope for positive feedback to encourage them. However, Brookhart [4] has argued that constructive criticism is welcomed in the classroom.

Swedish students tend to associate teachers' assessments heavily with assessing exams and giving course grades; in other words, with somewhat typical forms of assessment in teaching. Interestingly, the mean for giving feedback was the lowest in Swedish. A previous study [56] discovered that many Swedish teachers do not give feedback to pairs, groups, or the whole class during lessons. Consequently, Swedish students might be accustomed to not receiving feedback from Swedish teachers, which is extremely alarming. A lack of feedback means that students are not aware of their weaknesses and what they should improve [57].

As the core curriculum [1] stipulates that teachers should give feedback to their students, one unanticipated finding was that students do not perceive feedback to be an essential part of language teachers' assessment practices. One Swedish student even wrote that he or she had never received feedback from Swedish teachers in basic or general upper secondary school. This observation is in agreement with Baran-Lucarz [58], who found that some students claim not to have received feedback at all from teachers. Even if this remark 
can be subject to criticism, it raises an interesting question of whether students notice teachers' feedback (see [40]), since formative assessment is not as apparent as summative assessment [57]. As feedback should be a dialog between a student and a teacher [59], we suggest that teachers should make their feedback practices clearer to students and engage students in discussions on the feedback.

With regard to schools, feedback seems to be a more apparent form of assessment for students from average schools. We speculate that this might be due to the differences in the school cultures: teachers in reputable schools might think that students already possess the capabilities needed to acquire the skills and abilities for self-regulated learning. The students at reputable schools also had better previous course grades. As a result, teachers might not necessarily perceive feedback and the learning process to be so vital for the assessment. These insights, albeit tentative, are alarming, as students at reputable schools do not necessarily get better results in the matriculation examination than students at other schools [60]. However, feedback is a requirement for effective assessment and students need feedback during the learning process [18]. There is also some evidence that suggests that Finnish students would like to get more feedback during the learning process [34]. Taking these findings into account, we argue that foreign language teachers should pay more attention to the learning process of their students and ensure that they provide feedback on it. Moreover, especially in reputable schools, teachers should critically reflect on their assessment practices and ponder whether they take the learning process into account in their assessment practices and give enough feedback to students.

As the quantitative results demonstrate, feedback is not regarded to be a vital component in the concept of teachers' assessment practices. One plausible explanation for this might be "generally low levels of student feedback literacy". This term can be conceptualized as the understanding of what feedback means and how it can be used [61] (p. 1316). If students lack the knowledge of what feedback refers to and how it can be used to accelerate learning, it is not so surprising that they do not associate it with teachers' assessment practices. Especially since teachers' formative assessment practices help students take control over their learning [62], it is instrumental for students to understand the value of feedback. Similarly, students should understand the distinct functions of assessment to advance in their studying and become self-regulated learners [63], which is also one of the objectives of the core curriculum [1]. One of the issues that emerges from these findings is that more attention should be paid to the advancement of student feedback literacy, which would enable students to understand how assessment advances their learning.

Contrary to expectations, none of the students mentioned technology-enhanced feedback as a source of encouraging feedback, which contrasts with Oinas et al. [13] who found that several teachers tried to encourage students with technology-enhanced feedback, although these authors studied basic education. The matriculation examination is completely electronic in Finland and course books are available both in print and electronic versions. Therefore, laptops and online platforms are a common feature of Finnish general upper secondary schools, meaning that one would assume that at least some students would mention technology-enhanced feedback. However, some studies have demonstrated that teachers do not use technology for formative assessment [64] and that teachers face some challenges in implementing formative assessment practices, such as class size and lack of competencies [65]. Another unanticipated finding was that few students wanted individual feedback. If teachers want to support the engagement of students, on-going dialogue between students and teachers is needed [59], which is easy to achieve in individual feedback. However, students scarcely ever engage with the feedback processes [66]. Therefore, more emphasis should be put on how to improve students' engagement with teachers' feedback practices. Additionally, the French students did not consider assessing oral work to be an essential part of teachers' assessment practices, which is surprising as French students do not exhibit high proficiency in speaking French [67].

With regard to language teacher education, the results in this study indicate that more emphasis should be placed on the importance of formative assessment and feed- 
back in assessment courses, thereby helping teacher students understand how feedback guides and accelerates students' learning. Studies have shown that research-based instruction can modify student teachers' conceptions of assessment $[68,69]$; thus, this type of instruction could be used in assessment courses. Furthermore, international research has established that many teachers exhibit insufficient knowledge of formative assessment practices (e.g., $[70,71])$. Therefore, student teachers should be given more opportunities to practice how to give feedback to students to enhance their knowledge of formative assessment and feedback since teacher education plays a pivotal role in enhancing student teachers' knowledge of assessment [68].

Finally, several potential shortfalls of this study need to be considered. First, the participants were not randomly chosen for this study and many of them came from the metropolitan area of Helsinki. Second, the number of students for each language varied and, ideally, the number of students could have been more evenly distributed across genders. Third, due to the small sample size, the results are not generalizable and the results regarding French students are especially tentative. Fourth, the sample size could have been expanded by including more students from other parts of Finland. Notwithstanding the limitations mentioned above, this study constitutes an excellent initial step toward enhancing feedback practices in foreign language classes in Finnish general upper secondary schools.

\section{Conclusions}

The following conclusions can be drawn from the present study: students appreciate teacher feedback and they particularly want to receive feedback on the content of the work. Regarding teacher assessment practices, students do not perceive feedback to be a crucial part of them. However, students at average schools find feedback to be a more important part of teacher assessment practices than students at reputable schools. The importance of feedback and formative assessment should also be underscored more in language teacher education. Moreover, there is abundant room for further progress in elucidating what encouraging feedback means for students at different proficiency levels and whether gender affects students' perceptions of encouraging feedback. Personal interviews could also elicit greater information concerning encouraging feedback in foreign language teaching. Moreover, further research is required to establish the relationship between diverse feedback and assessment practices in schools. As this study focused only on teachers' feedback, more research is needed to assess encouraging feedback in peer feedback.

Author Contributions: Conceptualization, T.M.; methodology, T.M.; software, not applicable.; validation, T.M.; formal analysis, T.M.; investigation, T.M.; resources, not applicable; data curation, T.M.; writing-original draft preparation, T.M. and R.H.; writing-review and editing, T.M. and R.H.; visualization, T.M.; supervision, R.H.; project administration, T.M.; funding acquisition, T.M. All authors have read and agreed to the published version of the manuscript.

Funding: This research was partially funded by the Swedish Cultural Foundation in Finland.

Informed Consent Statement: Informed consent was obtained from all subjects involved in the study.

Data Availability Statement: The data are not publicly available due to the fact that the data can only be used in Toni Mäkipää's PhD studies.

Acknowledgments: We would like to thank the anonymous reviewers for their insightful comments and the students for participating in this study.

Conflicts of Interest: The authors declare no conflict of interest.

\section{References}

1. FNBE. National Core Curriculum for General Upper Secondary Schools 2015; Finnish National Board of Education: Helsinki, Finland, 2016; Available online: https:/ /www.ellibslibrary.com/book/9789521362675 (accessed on 4 November 2020).

2. Matriculation Examination Board. 2020. Available online: https://www.ylioppilastutkinto.fi/ext/stat/FS2020A2011T2010.pdf (accessed on 25 November 2020). 
3. Mäkipää, T. Feedback practices in language classes in Finnish general upper secondary schools. Apples. J. Appl. Lang. Stud. 2020, 14, 103-123. [CrossRef]

4. Brookhart, S.M. How to Give Effective Feedback to Your Students, 2nd ed.; ASCD: Alexandria, VA, USA, 2017.

5. General Upper Secondary Schools Act, 714/2018. Available online: https://www.finlex.fi/fi/laki/ajantasa/2018/20180714 (accessed on 4 November 2020).

6. Furtak, E.M.; Kiemer, K.; Circi, R.K.; Swanson, R.; de León, V.; Morrison, D.; Heredia, S.C. Teachers' formative assessment abilities and their relationship to student learning: Findings from a four-year intervention study. Instr. Sci 2016, 44, 267-291. [CrossRef]

7. Heritage, M. Formative Assessment: What Do Teachers Need to Know and Do? Phi Delta Kappan. 2007, 89, 140-145. [CrossRef]

8. Xiao, Y.; Yang, M. Formative assessment and self-regulated learning: How formative assessment supports students' self-regulation in English language learning. System 2019, 81, 39-49. [CrossRef]

9. Price, M.; Handley, K.; Millar, J. Feedback: Focusing on engagement. Stud. High. Educ. 2011, 36, 879-896. [CrossRef]

10. Weaver, M.R. Do students value feedback? Student perceptions of tutors' written responses. Assess. Eval. High. Educ. 2006, 31, 379-394. [CrossRef]

11. Doan, L. Is Feedback a Waste of Time? The Students' Perspective. J. Pers. Appl. Acad. Pract. 2013, 1, 3-10. [CrossRef]

12. Núňez, J.C.; Suárez, N.; Rosário, P.; Vallejo, G.; Cerezo, R.; Valle, A. Teachers' Feedback on Homework, Homework-Related Behaviors, and Academic Achievement. J. Educ. Res. 2015, 108, 204-216. [CrossRef]

13. Oinas, S.E.; Thuneberg, H.; Vainikainen, M.-P.; Hotulainen, R. Technology-enhanced Feedback Profiles and their Associations with Learning and Academic Well-being Indicators in Basic Education. Contemp. Educ. Technol. 2020, 12, 1-15. [CrossRef]

14. Vogt, K.; Tsagari, D. Assessment literacy of foreign language teachers: Findings of a European study. Lang. Assess. Q. 2014, 11, 374-402. [CrossRef]

15. Huhta, A.; Hildén, R. (Eds.) Kielitaidon Arviointitutkimus 2000-Luvun Suomessa; Finnish Association of Applied Linguistics: Jyväskylä, Finland, 2016.

16. Bachman, L.; Damböck, B. Language Assessment for Classroom Teachers; Oxford University Press: Oxford, UK, 2018.

17. Sheen, Y.; Ellis, R. Corrective feedback in language teaching. In Handbook of Research in Second Language Teaching and Learning; Hinkel, E., Ed.; Routledge: New York, NY, USA, 2011; Volume II, pp. 593-610.

18. Hattie, J.; Timperley, H. The Power of Feedback. Rev. Educ. Res. 2007, 77, 81-112. [CrossRef]

19. Black, P.; Wiliam, D. Classroom Assessment and Pedagogy. Assess. Educ. 2018, 25, 551-575. [CrossRef]

20. Ajjawi, R.; Boud, D. Researching feedback dialogue: An interactional analysis approach. Assess. Eval. High. Educ. 2017, 42, 252-265. [CrossRef]

21. Ellis, R.; Shintani, N. Exploring Language Pedagogy through Second Language Acquisition Research; Routledge: Abingdon, UK, 2014.

22. Bandura, A. (Ed.) Self-Efficacy in Changing Societies; Cambridge University Press: Cambridge, UK, 1995.

23. Jakobson, L. Holistic perspective on Feedback for adult beginners in an online course of Swedish. Apples. J. Appl. Lang. Stud. 2015, 9, 51-71. [CrossRef]

24. McMartin-Miller, C. How much feedback is enough? Instructor practices and student attitudes toward error treatment in second language writing. Assess. Writ. 2014, 19, 24-35. [CrossRef]

25. Martin, S.; Alvarez Valdivia, I.B. Students' feedback beliefs and anxiety in online foreign language oral tasks. Int. J. Educ. Technol. High. Educ. 2017, 14, 1-15. [CrossRef]

26. Vattoy, K.-D.; Smith, K. Students' perceptions of teachers' feedback practice in teaching English as a foreign language. Teach. Teach. Educ. 2019, 85, 260-268. [CrossRef]

27. van der Kleij, F.M. Comparison of teacher and student perceptions of formative assessment feedback practices and association with individual student characteristics. Teach. Teach. Educ. 2019, 85, 175-189. [CrossRef]

28. Tom, A.A.; Morni, A.; Metom, L.; Joe, S. Students' Perception and Preferences of Written Feedback in Academic Writing. Mediterr. J. Soc. Sci. 2013, 4, 72-80. [CrossRef]

29. Amrhein, H.R.; Nassaji, H. Written Corrective Feedback: What Do Students and Teachers Prefer and Why? Can. J. Appl. Linguist. 2010, 13, 95-127.

30. Brooks, C.; Huang, Y.; Hattie, J.; Carroll, A.; Burton, R. What Is My Next Step? School Students' Perceptions of Feedback. Front. Educ. 2019, 96, 1-14. [CrossRef]

31. Peterson, E.R.; Irving, S.E. Secondary school students' conceptions of assessment and feedback. Learn. Instr. 2008, 18, 238-250. [CrossRef]

32. Elwood, J.A.; Bode, J. Student preferences vis-à-vis teacher feedback in university EFL writing classes in Japan. System 2014, 42, 333-343. [CrossRef]

33. Hedgcock, J.; Lefkowitz, N. Some Input on Input: Two Analyses of Student Response to Expert Feedback in L2 Writing. Mod. Lang. J. 1996, 80, 287-308. [CrossRef]

34. Pollari, P. To feed back or to feed forward? Students' experiences of and responses to feedback in a Finnish EFL classroom. Apples. J. Appl. Lang. Stud. 2017, 11, 11-33. [CrossRef]

35. Vattoy, K.-D. Teachers' beliefs about feedback practice as related to student self-regulation, self-efficacy, and language skills in teaching English as a foreign language. Stud. Educ. Eval. 2020, 64, 1-12. [CrossRef] 
36. Ilola, M. Oppilaiden käsityksiä englannin suullisesta kielitaidosta—Suuntaviivoja suullisen kielitaidon opetukseen ja arviointiin. In Kielididaktiikan Katse Tulevaisuuteen: Haasteita, Mahdollisuuksia Ja Uusia Avauksia Kielten Opetukseen; Hildén, R., Hahl, K., Eds.; Suomen ainedidaktisen tutkimusseuran julkaisuja, Ainedidaktisia tutkimuksia 17: Helsinki, Finland, 2020; pp. 129-151.

37. Pollari, P. “Mitä pitäisi kehittää ja miten?” Lukiolaisten kokemuksia arvioinnista ja sen menetelmistä englannin opinnoissa. In Kielididaktiikan Katse Tulevaisuuteen: Haasteita, Mahdollisuuksia Ja Uusia Avauksia Kielten Opetukseen; Hildén, R., Hahl, K., Eds.; Suomen ainedidaktisen tutkimusseuran julkaisuja, Ainedidaktisia tutkimuksia 17: Helsinki, Finland, 2020; pp. 153-171.

38. Pollari, P. The power of assessment: What (dis)empowers students in their EFL assessment in a Finnish upper secondary school? Apples. J. Appl. Lang. Stud. 2017, 11, 147-175. [CrossRef]

39. Atjonen, P.; Laivamaa, H.; Levonen, A.; Orell, S.; Saari, M.; Sulonen, K.; Tamm, M.; Kamppi, P.; Rumpu, N.; Hietala, R.; et al. "Että Tietää Missä on Menossa" Oppimisen ja Osaamisen Arviointi Perusopetuksessa ja Lukiokoulutuksessa; Publications of the Finnish Education Evaluation Centre (FINEEC): Tampere, Finland, 2019; Available online: https://karvi.fi/app/uploads/2019/04/ KARVI_0719.pdf (accessed on 31 August 2020).

40. Mäkipää, T.; Ouakrim-Soivio, N. Perceptions of Finnish Upper Secondary School Students of the Assessment Practices of Their Teachers. J. Teach. Learn. 2019, 13, 23-42. [CrossRef]

41. Dörnyei, Z.; Ushioda, E. Teaching and Researching Motivation, 2nd ed.; Routledge: New York, NY, USA, 2011.

42. Ryan, R.M.; Deci, E.L. Self-determination theory and the facilitation of intrinsic motivation, social development, and well-being. Am. Psychol. 2000, 55, 68-78. [CrossRef]

43. Ryan, R.M.; Deci, E.L. Intrinsic and Extrinsic Motivations: Classic Definitions and New Directions. Contemp. Educ. Psychol. 2000, 25, 54-67. [CrossRef]

44. Gardner, R.C.; Lambert, W.E. Motivational variables in second-language acquisition. Can. J. Psychol. 1959, 13, 266-272. [CrossRef]

45. Dörnyei, Z. The Psychology of the Language Learner. Individual Differences in Second Language Acquisition; Routledge: New Jersey, NJ, USA, 2005.

46. Cauley, K.M.; McMillan, J.H. Formative Assessment Techniques to Support Student Motivation and Achievement. Clear. House 2010, 83, 1-6. [CrossRef]

47. Dörnyei, Z. Motivational Strategies in the Language Classroom; Cambridge University Press: Cambridge, UK, 2001.

48. Murtagh, L. The motivational paradox of feedback: Teacher and student perceptions. Curric. J. 2014, 25, 516-541. [CrossRef]

49. Pat-El, R.; Harm, T.; van Koppen, S.W.M. Effects of formative feedback on intrinsic motivation: Examining ethnic differences. Learn. Individ. Differ. 2012, 22, 449-454. [CrossRef]

50. Weurlander, M.; Söderberg, M.; Scheja, M.; Hult, H.; Wernerson, A. Exploring formative assessment as a tool for learning: Students' experiences of different methods of formative assessment. Assess. Eval. High Educ. 2012, 37, 747-760. [CrossRef]

51. Tirri, K.; Kuusisto, E. How Finland Serves Gifted and Talented Pupils. J. Educ. Gift. 2013, 36, 84-96. [CrossRef]

52. Mayring, P. Qualitative Content Analysis (28 paragraphs). Forum Qual. Soc. Res. 2000, 1, 20.

53. Drisko, J.; Maschi, T. Content Analysis; Oxford University Press: New York, NY, USA, 2015. [CrossRef]

54. Brown, V.; Clarke, V. Successful Qualitative Research: A Practical Guide for Beginners; Sage: Los Angeles, CA, USA, 2013.

55. Härmälä, M.; Hildén, R.; Leontjev, D. Yhdeksäsluokkalaisten opiskelukäytänteet englannin, ruotsin ja ranskan oppitunneilla [The study practices of 9th graders in English, Swedish, and French lessons and spare time]. In In Kielitaidon arviointitutkimus 2000-luvun Suomessa [Research on Language Assessment in the 21st Century Finland]; Huhta, A., Hildén, R., Eds.; Finnish Association of Applied Linguistics: Jyväskylä, Finland, 2016; pp. 142-166.

56. Tuokko, E. Miten ruotsia osataan peruskoulussa? Perusopetuksen päättövaiheen ruotsin kielen B-oppimäärän oppimistulosten kansallinen arviointi 2008 [How is Swedish mastered in basic education? National evaluation of the learning outcomes in B level Swedish after basic education 2008]; Finnish National Agency for Education: Helsinki, Finland, 2009.

57. Ketabi, S.; Ketabi, S. Classroom and Formative Assessment in Second/Foreign Language Teaching and Learning. Theory. Pract. Lang. Stud. 2014, 4, 435-440. [CrossRef]

58. Baran-Lucarz, M. Formative assessment in the English as a foreign language classroom in secondary schools in Poland. Report on a mixed-method study. J. Educ. Cult. Soc. 2019, 10, 309-327. [CrossRef]

59. Pryor, P.; Crossouard, B. A socio-cultural theorisation of formative assessment. Oxf. Rev. Educ. 2008, 34, 1-20. [CrossRef]

60. Tervonen, L.; Kortelainen, M.; Kanninen, O. Eliittilukioiden Vaikutukset Ylioppilaskirjoitusten Tuloksiin [The Effects of Elite General Upper Secondary Schools on the Results of the Matriculation Examination]; VATT Institute for Economic Research: Helsinki, Finland, 2017.

61. Carless, D.; Boud, D. The Development of student feedback literacy: Enabling uptake of feedback. Assess. Eval. High. Educ. 2018, 43, 1315-1325. [CrossRef]

62. Nicol, D. Assessment for learner self-regulation: Enhancing achievement in the first year using learning technologies. Assess. Eval. High. Educ. 2009, 34, 335-352. [CrossRef]

63. Smith, C.D.; Worsfold, K.; Davies, L.; Fisher, R.; McPhail, R. Assessment literacy and student learning: The case for explicitly developing students 'assessment literacy. ' Assess. Eval. High. Educ. 2013, 38, 44-60. [CrossRef]

64. Johnson, C.C.; Sondergeld, T.A.; Walton, J.B. A Study of the Implementation of Formative Assessment in Three Large Urban Districts. Am. Educ. Res. J. 2019, 56, 2408-2438. [CrossRef]

65. Figa, J.G.; Tarekegne, W.M.; Kebede, M.A. The Practice of Formative Assessment in Ethiopian Secondary School Curriculum Implementation: The Case of West Arsi Zone Secondary Schools. Educ. Assess. 2020. [CrossRef] 
66. Winstone, N.E.; Nash, R.A.; Parker, M.; Rowntree, J. Supporting learners' agentic engagement with feedback: A systematic review and a taxonomy of recipience processes. Educ. Psychol. 2017, 52, 17-37. [CrossRef]

67. Härmälä, M.; Huhtanen, M. Ranskan Kielen A-ja B-Oppimäärän Oppimistulokset Perusopetuksen Päättövaiheessa 2013 [Outcomes of Learning in A and B Level French at the End of Basic Education in 2013]; Finnish National Agency for Education: Tampere, Finland, 2014.

68. DeLuca, C.; Chavez, T.; Cao, C. Establishing a foundation for valid teacher judgement on student learning: The role of pre-service assessment education. Assess. Educ. Princ. Pol. Pract. 2013, 20, 107-126. [CrossRef]

69. Hildén, R.; Fröjdendahl, B. The dawn of assessment literacy-Exploring the conceptions of Finnish student teachers in foreign languages. Apples. J. Appl. Lang. Stud. 2018, 12,1-24. [CrossRef]

70. Arrafi, M.A.; Sumarni, B. Teachers' understanding of formative assessment. Lingua Cultura 2018, 12, 45-52. [CrossRef]

71. Bennett, R.E. Formative assessment: A critical review. Assess. Educ. Princ. Pol. Pract. 2011, 18, 5-25. [CrossRef] 